\title{
THE FAMILY MENTORING PROGRAM (FMP) ON IMPROVEMENT OF NUTRITIONAL STATUS
}

\author{
Iwan Shalahuddin ${ }^{1}$, Theresia Eriyani ${ }^{2}$, Riyanti $^{3}$ \\ 1 Lecturer in Community Department, Faculty of Nursing, University of Padjadjaran, Indonesia \\ Email: Shalahuddin.iwan@gmail.com \\ ${ }^{2}$ Lecturer in Faculty of Nursing, University of Padjadjaran, Indonesia. Email: theresiaeriyani@gmail.com \\ 3Lecturer in Faculty of Public Health, Malahayati University, Bandar Lampung, Indonesia. \\ Email: riri_warna@yahoo.co.id
}

\begin{abstract}
Background: Cases of poor nutritional status in toddlers can be found in families that are materially classified as rich, this is due to clean and healthy living behavior that is not in accordance with health standards. In Girimukti Village, Cibatu Health Center, Garut Regency, the majority condition of the education is in low level and only $1591(32 \%)$ of 5569 patriarch had passed Junior High School, and has income in low level, between $300-500$ thousand (IDR) per month.

Purpose: Knowing The effect of family mentoring program (FMP) on improvement of nutritional status

Methods: The type of this study was quasi experimental with pretest, posttest and control design with pretestposttest quasi experimental design. The study sample was carried out using stratified random sampling with a population of malnourished mothers and under-fives for the Girimukti village area, the working area of Cibatu Community Health Center was 61 people.

Results: Statistical test results with a confidence level of $95 \%$ showed that there were changes in parents' knowledge about nutrition. The average change in calorie intake consumed by toddlers in the treatment group reached $6.92 \%$ of the original calorie intake and the average change in calorie intake consumed in the control group reached $2.10 \%$ of the original calorie intake. The results of statistical tests show that there are significant differences in the average changes in calorie intake consumed by toddlers between the treatment group and the control group $(p<0.05)$.

Conclusion: From the results of the study it can be concluded that the knowledge and attitudes of mothers of children under five who received family nursing care by students were better than mothers who did not receive family nursing care.
\end{abstract}

\section{Keywords: The family mentoring program (FMP), toddler, nutritional status}

\section{INTRODUCTION}

Poverty experienced by some residents does have a very serious impact on the nutritional status of their family members, especially children. Based on the data inventory of the West Java Provincial Health Office, cases of malnutrition were found evenly throughout West Java, especially in the pockets of poverty (Dinas Kesehatan Provinsi Jawa Barat, 2011).

Reported in September 2013 in Garut regency there were 203,111 households or $35.36 \%$ of households categorized as poor, out of 262,318 under-fives in Garut Regency as many as 2282 or $0,87 \%$ were in poor nutritional status and $12.62 \%$ or 3310 is in malnutrition. Cases of poor nutritional status in toddlers can also be found in families that are materially classified as rich, this is due to clean and healthy living behavior that is not in accordance with health standards. The Garut Regency Government through the Department of Health seeks to tackle nutritional problems by issuing policies, strategies, activity plans that must be followed up by Puskesmas officers. (Fidiantoro, \& Setiadi, 2013). However, due to limited energy and breadth of the area, the nutrition prevention program was less successful.

Efforts to improve the quality of human resources are closely related to the ability of the community to meet food needs with balanced nutrition. Fulfillment of balanced nutrition needs is especially needed since the fetus to five-year-old child, because this period is a vulnerable period for children or often called the Golden age (Ministry of Health of the Republic of Indonesia, 2013)

Children suffering from calorie-protein malnutrition are at high risk of death, and need treatment careful at the hospital. Children with poor nutritional status should get attention from mothers and officers so that malnutrition does not occur. Most people who have malnourished toddlers doing self-care at home are very risky because not 
all mothers / patriarch have expertise in caring for malnourished patients (Khoiri, 2009).

For the successful treatment of malnourished toddlers at the household level, participation from health workers is needed, this can be done by health workers by providing guidance, assistance and assistance for families through home visits (Ayu, 2008). Home visits by officers on families of toddlers with nutritional disorders, officers can find out the problems faced by the family and make management for nutritional status disorders of the toddler by utilizing the potential of the family in problem solving, (Ministry of Health, RI 2011).

In Girimukti Village Cibatu Garut Community Health Center working area the education level of the community is low, of the Level 5569 people and 1591 Family Heads, 32\% are First Advanced School (SLTP). Income is also low, which is between 300 - 500 thousand per month. The number of toddlers in this region is quite high at 556 people. Of these, those who experience malnutrition 139. To overcome this problem, the Puskesmas has special tips through the application of family nursing care. Family nursing care is a strategic activity to overcome family health problems by utilizing the potential of the family. This nursing care is specific to overcome problems through assessment, determine problems, plan actions, implement and evaluate (Ali, 2010).

Based on the views of these two opinions, it can be concluded that field practice can hone the knowledge, attitudes and skills of students as well as families who have health problems. Based on the background of nutritional problems in the field and the role of family nursing practitioners in the field, research on the effect of family nursing care on increase in nutritional status by students.

\section{RESEARCH METHODS}

The type of research is quasi-experimental with pretest, posttest and control design, because of the treatment given to subjects with control (Jaedun, 2011). The population in this study were all underweight children under five in Girimukti Village Cibatu Health Center, who received family coaching by students. The sample was conducted using stratified random sampling technique (Martono, 2010) with a population of malnourished children and toddlers for Girimukti Village Cibatu Health Center area is 139 people. Of these, 75 people were eligible to be sampled.

The research respondents were mothers and toddlers with less nutrition in the Cibatu Health Center area of 75 people. The variables needed in this study are independent variables (independent) and dependent variables (dependent). In data collection techniques involving semester $\mathrm{V}$ students who are carrying out the practice of builtup families for 2 weeks with home visits every day, because this study takes 4 weeks then the second week still involves students but with a home visit every 3 days.

The control group is used to minimize errors in conclusions. The unit of analysis in this study was malnutrition, in the treatment group was given family care care by students of the Garut Regency Government in the framework of the practice of family coaching. The number of malnourished toddlers who were sampled was 76 people, during the process of 6 sick people, 3 people were taken away by their families, 1 person was cared for by his grandmother. The treatment group was taken as many as 66 people and in the control group 65 people were taken.

The objects studied included maternal knowledge of nutrition, maternal attitudes toward food processing and treatment of under-nutrition, toddler nutrition and improvement in nutritional status of children. Data collection was carried out in two stages, the first stage of the data was collected before family care was carried out by the student towards the treatment group, at the same time data from the control group were also collected. Furthermore, students gave family care to the treatment group with a duration of approximately one month. Furthermore, the same data as before the treatment was collected again, both in the treatment group and the control group.

Iwan Shalahuddin' Lecturer in Community Department, Faculty of Nursing, University of Padjadjaran, Indonesia Email: Shalahuddin.iwan@gmail.com

Theresia Eriyani ${ }^{2}$ Lecturer in Faculty of Nursing, University of Padjadjaran, Indonesia. Email: theresiaeriyani@gmail.com Riyanti ${ }^{3}$ Lecturer in Faculty of Public Health, Malahayati University, Bandar Lampung, Indonesia.

Email: riri_warna@yahoo.co.id 


\section{RESEARCH RESULTS AND DISCUSSION}

Table 1. Parents' Knowledge Regarding Nutrition

\begin{tabular}{lccc}
\hline & & \multicolumn{2}{c}{ Group } \\
\cline { 3 - 4 } Knowledge of Nutrition & $\begin{array}{c}\text { Treatment } \\
(\mathbf{n = 6 6 )}\end{array}$ & $\begin{array}{c}\text { Control } \\
(\mathbf{n}=\mathbf{6 5})\end{array}$ \\
\hline $\begin{array}{l}\text { 1. Before Treatment } \\
\text { Very Good }\end{array}$ & Freq (\%) & $14(21.2)$ & $10(15.4)$ \\
Good & Freq (\%) & $14(21.2)$ & $4(6.2)$ \\
Enough Good & Freq (\%) & $33(50.0)$ & $46(70.8)$ \\
Poor & Freq (\%) & $5(7.6)$ & $5(7,7)$ \\
2. After Treatment & & & \\
Very Good & Freq (\%) & $40(60.6)$ & $4(6.2)$ \\
Good & Freq (\%) & $9(13.6)$ & $11(16.9)$ \\
Fairly Good & Freq (\%) & $14(21.2)$ & $47(72.3)$ \\
Poor Good & Freq (\%) & $3(4,5)$ & $3(4,6)$ \\
\hline
\end{tabular}

Based on table 1 shows that with the care of family care given by students attitudes of parents of toddlers regarding food processing and the treatment of under five toddlers is increasing. That is, before treatment, a small percentage of majority of respondents had very good knowledge as many as 14 people (21.2\%), and after getting treatment the respondents were very good as many as 40 people $(60.6 \%)$, there was an increase of 26 people $(39,4 \%)$.

Table 2. Parents' Attitudes Regarding Nutrition

\begin{tabular}{llll}
\hline & & \multicolumn{2}{c}{ Group } \\
\cline { 3 - 4 } Parents' Attitudes Regarding Nutrition & $\begin{array}{c}\text { Treatment } \\
(\mathbf{n = 6 6 )}\end{array}$ & $\begin{array}{c}\text { Controls } \\
(\mathbf{n}=65)\end{array}$ \\
\hline $\begin{array}{llll}\text { 1. Before Treatment } \\
\quad \text { Supports }\end{array}$ & Freq (\%): & $37(56,1)$ & $31(47,7)$ \\
$\quad$ Less Supporting & Freq (\%): & $29(43.9)$ & $34(52.3)$ \\
2. After Treatment & & & \\
$\quad$ Supports & Freq (\%): & $49(74,2)$ & $22(33,8)$ \\
$\quad$ Less Supporting & Freq (\%): & $17(25,8)$ & $43(66.2)$ \\
\hline
\end{tabular}

At the beginning of the study, that before being given family care by students, it can be seen that most $(56.1 \%)$ attitudes of toddlers' parents regarding food processing and were lacking in the treatment group in the support category. At the end of the study, that after being given family care by students, it can be seen that most $(74.2 \%)$ attitudes of toddlers' parents regarding food processing and were lacking in the treatment group in the support category. In contrast to the control group, where at the beginning of the study can be seen most of the attitudes of toddlers' parents regarding food processing and under-nutrition care were in the category of underpinning 17 people $52 \%$, as well as at the end of the study most of the attitudes of toddler parents regarding food processing and care The lack of nutrition was in the category of less supportive $66.2 \%$. But the same thing happened in the control group.

Iwan Shalahuddin' Lecturer in Community Department, Faculty of Nursing, University of Padjadjaran, Indonesia Email: Shalahuddin.iwan@gmail.com

Theresia Eriyani ${ }^{2}$ Lecturer in Faculty of Nursing, University of Padjadjaran, Indonesia. Email: theresiaeriyani@gmail.com Riyanti ${ }^{3}$ Lecturer in Faculty of Public Health, Malahayati University, Bandar Lampung, Indonesia. 
Bivariate analysis of different tests on two samples related or using the test paired. The data that will be analyzed bivariate include the knowledge and attitudes of the toddler's mother regarding food processing and treatment and nutritional status.

At the beginning of the study the measurement of education level in the treatment group was 68.86 $(17.7 \%)$ while the control group was $64.31(15.6 \%)$, after treatment the knowledge treatment group was $82.95(18.4 \%)$ while the control group to 64.45 . The highest knowledge of parents about nutrition in the highest treatment group became 33 people after one month of upbringing increased to a very good category, as many as 40 people. While in the control group the study was dominated by 46 people after one month an increase of 1 person became 47 people.

Level of knowledge of parents of toddlers regarding nutrition between treatment groups and the control group ( $p>0.05)$. At the end of the study, after being given family care by students to the treatment group, it showed a significant difference in the knowledge of parents of children under five $(p<0.05)$. Thus Ho in the above hypothesis was rejected and $\mathrm{Ha}$ was accepted, so that with a confidence level of $95 \%$ It can be concluded that there is a change in parents' knowledge about nutrition after receiving family care by students, with a one-month home visit. The results of this study are reinforced by other studies which conclude that there is a positive influence of health education given to mothers who have children about the provision of nutritional intake and there is a significant relationship between maternal knowledge of nutrition and cognitive development of children (Sangwan, \& Manocha, 2009; Dasuki, Utama, \& Pramuningtyas, 2011).

Changes in attitudes of the results of the initial measurements before the study for treatment were $51.23 \%$ while controls were $48.75 \%$. At the beginning of the study, the attitudes of parents of toddlers regarding food processing and nutritional care of toddlers in the treatment group, in the supporting category were 37 people and were less supportive of 29 people. The control group 31 people supported and 34 people were less supportive. After treatment for one month, for the treatment group $54.52 \%$ while the control $45.41 \%$ in the treatment group that supports 49 people and is less supportive of 17 people. While the control group 22 people support and 43 people are less supportive. Changes in attitudes of parents of toddlers regarding food processing and treatment of malnourished toddlers in the treatment group increased $9.49 \%$ from the original score. In contrast to the control group it actually decreased by $2.31 \%$ from the original score. In accordance with the results of research conducted by Karimawati, Widodo, \& Listyorini, (2013) which stated the difference in attitudes of respondents after being given health education. It can be concluded that there is a positive influence on health education given to mothers who have toddler children about providing nutritional intake.

The average change in calorie intake consumed by toddlers in the treatment group reached $6.92 \%$ of the original calorie intake and the average change in calorie intake consumed in the control group reached $2.10 \%$ of the original calorie intake. Statistical results showed that there were significant differences in the average changes in calorie intake consumed by between treatment groups and the control group toddlers (Kadarhadi, Mexitalia, \& Puruhita, 2012)

Average changes in protein intake consumed by toddlers in the treatment group reached 12 , $66 \%$ of the original protein intake and the average change in protein intake consumed Toddlers in the control group reached $0.61 \%$ of the original protein intake. The results of statistical tests showed that there were significant differences in the average changes in protein intake consumed by toddlers between the treatment group and the control group $(p<0.05)$.

The average change in height of toddlers in the treatment group reached $0.70 \%$ of height. initially and the average change in height of toddlers in the control group reached $0.30 \%$ of the original height. The results of statistical tests showed that there were significant differences in the mean changes in height of toddlers between treatment groups and the control group $(p<0.05)$. In line with the results of the study stating the existence of differences in the control group and treatment in giving counseling seen from the growth of changes in height in children under five (Fitriyanti, \& Mulyati, 2012).

The average increase in toddler weight in the treatment group reached $3.22 \%$ of the weight

Iwan Shalahuddin' Lecturer in Community Department, Faculty of Nursing, University of Padjadjaran, Indonesia Email: Shalahuddin.iwan@gmail.com

Theresia Eriyani ${ }^{2}$ Lecturer in Faculty of Nursing, University of Padjadjaran, Indonesia. Email: theresiaeriyani@gmail.com Riyanti ${ }^{3}$ Lecturer in Faculty of Public Health, Malahayati University, Bandar Lampung, Indonesia. 
original body and average increase in body weight of toddlers in the control group reached $0.58 \%$ of the original body weight. The results of statistical tests showed that there were significant differences in the mean increase in underweight between treatment groups and the control group $(p<0.05)$.

At the beginning of the study the measurement of knowledge level in the treatment group was $68.86(17.7 \%)$ while the control was $64.31(15.6 \%)$. after treatment in the treatment group the level of knowledge became 82.95 (18.4\%) while the control became 64.45. Most parents' knowledge of nutrition in the highest treatment group was a fairly good category of 33 people after being given care for one month increasing to very good katerogi, as many as 40 people. Whereas in the control group before the study was dominated by quite good 46 people after one month there was an increase of 1 person to 47 people.

The average increase in changes in maternal nutrition knowledge in the treatment group increased by $28.85 \%$ from the original score. While in the control group the increase was $3.22 \%$. The statistical test results showed significant differences between the treatment and control groups $(p<0.05)$. In accordance with the results of the study stating that the change in mean knowledge, attitudes, practices, energy, protein, iron, zinc, and calcium intake from the beginning to the end of the study, had a significant difference ( $p$ $<0.05$ ) between the control and treatment groups.increase was found in the treatment group than in the control group Greater (Hestuningtyas, \& Noer, 2014).

Discussion of the effect of family nursing care on changing attitudes of parents. Looking at the results of the study on the average change in treatment attitudes, the improvement is not too optimal as expected so it needs deepening in training as well as the students' self-confidence itself needs to be improved so that they are more confident in their abilities. Nutrition for toddlers nutrition, family capability related to the quality and quantity of food consumption is supported by decision makers to consume food in the family (Salmah, 2012).

Looking at the results of research on 66 underfive children who were malnourished, it turned out that after the upbringing there was an increase in nutritional intake both protein and calories, but not too high because it was related to food security at the family level which was minimal, in accordance with the results of research that stated that direct factors had an effect on Child nutrition status includes unbalanced food and infection, while indirect causes include food security in the family, patterns of childcare and health and environmental health services (Devi, 2012). Where the income of between $\mathrm{Rp}$. 300-500 plus the market price situation which is very troublesome for mothers managing finances, so it has an impact on the quality and quantity of food supply in the family. The average change in protein intake consumed by toddlers in the treatment group reaches $12.66 \%$. from the original protein intake. While for the control group reached $6.92 \%$ of the original intake. The initial calorie intake in the treatment group was 55.29 while the control group was 57.12. After one month treatment in the treatment group became 59.04 and the control group 57.80 .

Differences in nutritional status of children under five years after nursing care is given by students compared to routine management by health workers. In addition to food security, the family level of time is one of the factors that play a role in improving the nutritional status of children ( Putri, Sulastri, \& Lestari, 2015). Nutritional status of toddlers at the beginning of the study with nutritional status of Toddlers at the end of the study showed a significant change both in the treatment group and in the control group ( $p<0.05)$. Thus Ho in the above hypothesis is rejected and $\mathrm{Ha}$ is accepted, so that with a 95\% confidence level it can be concluded that there is a change in the nutritional status of children after receiving family nursing care by students.

\section{CONCLUSION}

It can be concluded that the knowledge of mothers of children under five who receive family nursing care is better than mothers who do not receive family nursing care. The attitude of mothers of children under five who received family nursing care by students was better than mothers who did not receive family nursing care. Protein caloric intake of malnourished toddlers whose mothers receive family nursing care by students is higher than for toddlers whose mothers do not receive care. Nutritional status Toddlers whose mothers receive family nursing care have an increase

Iwan Shalahuddin' Lecturer in Community Department, Faculty of Nursing, University of Padjadjaran, Indonesia Email: Shalahuddin.iwan@gmail.com

Theresia Eriyani ${ }^{2}$ Lecturer in Faculty of Nursing, University of Padjadjaran, Indonesia. Email: theresiaeriyani@gmail.com Riyanti ${ }^{3}$ Lecturer in Faculty of Public Health, Malahayati University, Bandar Lampung, Indonesia. 
compared to toddlers who get routine management of health workers.

\section{SUGGESTIONS}

The nursing care should be used as a routine program by the Puskesmas in collaboration with nursing education institutions. The mother's knowledge and attitudes more time and effort are needed and mothers who have received care, knowledge and attitudes are still unstable need guidance from Puskesmas staff to intense then both knowledge and attitudes so that their behavior does not return, as well as their nutrition in addition to improving nutritional quality are also given care in collaboration with Posyandu cadres as direct field monitors to be detected as soon when any changes.

\section{REFERENCES}

Ali, H. Z. (2010). Pengantar keperawatan keluarga. EGC.

Dasuki, M. S., Utama, R. C., \& Pramuningtyas, R. (2011). Hubungan Pengetahuan Ibu tentang Gizi dengan Perkembangan Kognitif Anak Usia 24-59 Bulan

Devi, M. (2012). Analisis faktor-faktor yang berpengaruh terhadap status gizi balita di pedesaan. Teknologi dan Kejuruan, 33(2).

Dinas Kesehatan Provinsi jawa Barat (2011). Profil Kesehatan Tahun 2011. Dinas Kesehatan Provinsi Jawa Barat. Bandung.

Fidiantoro, N., \& Setiadi, T. (2013). Model penentuan status gizi balita di puskesmas. JSTIE (Jurnal Sarjana Teknik Informatika)(E-Journal), 1(1), 367373.

Fitriyanti, F., \& Mulyati, T. (2012). Pengaruh Pemberian Makanan Tambahan Pemulihan (PMTP) Terhadap Status Gizi Balita Gizi Buruk di Dinas Kesehatan Kota Semarang Tahun 2012 (Doctoral dissertation, Diponegoro University).

Hestuningtyas, T. R., \& Noer, E. R. (2014). Pengaruh Konseling Gizi Terhadap Pengetahuan, Sikap, Praktik Ibu Dalam Pemberian Makan Anak, dan Asupan Zat Gizi Anak Stunting Usia 1-2 Tahun di Kecamatan Semarang Timur (Doctoral dissertation, Diponegoro University).
Jaedun, A. (2011). Metodologi Penelitian Eksperimen. Fakultas Teknik UNY.

Kadarhadi, E., Mexitalia, M., \& Puruhita, N. (2012). Pengaruh konseling dengan "feeding rules" terhadap status gizi anak dengan kesulitan makan (Doctoral dissertation, Fakultas Kedokteran).

Karimawati, D., Widodo, A., \& Listyorini, D. (2013). Pengaruh Pendidikan Kesehatan terhadap Pengetahuan dan Sikap Ibu Mengenai Asupan Gizi pada Usia Toddler di Surakarta (Doctoral dissertation, Universitas Muhammadiyah Surakarta).

Kementrian Kesehatan Republik Indonesia. (2013). Pedoman pelayanan gizi rumah sakit. Jakarta: Kementrian Kesehatan RI.

Khoiri, I. F. (2009). Status gizi balita di posyandu kelurahan padang bulan Kecamatan Medan Baru. Status Gizi Balita Di Posyandu Kelurahan Padang Bulan Kecamatan Medan Baru.

Martono, N. (2010). Metode penelitian kuantitatif: Analisis Isi dan Analisis Data Sekunder (sampel halaman gratis). RajaGrafindo Persada

Putri, R. F., Sulastri, D., \& Lestari, Y. (2015). FaktorFaktor yang Berhubungan dengan Status Gizi Anak Balita di Wilayah Kerja Puskesmas Nanggalo Padang. Jurnal Kesehatan Andalas, 4(1).

Salmah, U. (2012). Gambaran Gizi Buruk Pada Balita di Wilayah Kerja Puskesmas Jongaya Tahun 2012 (Doctoral dissertation, Universitas Islam Negeri Alauddin Makassar).

Sangwan, S., \& Manocha, A. (2009). Maternal Knowledge and Child Health. Journal of Human Ecology, 25(1), 51-54.

Iwan Shalahuddin' Lecturer in Community Department, Faculty of Nursing, University of Padjadjaran, Indonesia Email: Shalahuddin.iwan@gmail.com

Theresia Eriyani ${ }^{2}$ Lecturer in Faculty of Nursing, University of Padjadjaran, Indonesia. Email: theresiaeriyani@gmail.com Riyanti ${ }^{3}$ Lecturer in Faculty of Public Health, Malahayati University, Bandar Lampung, Indonesia.

Email: riri_warna@yahoo.co.id 